BMJ Open

Sport \&

Exercise

Medicine

\title{
Are extreme conditioning programmes effective and safe? A narrative review of high-intensity functional training methods research paradigms and findings
}

\author{
Ramires Alsamir Tibana, ${ }^{1}$ Nuno Manuel Frade de Sousa ${ }^{2}$
}

\begin{abstract}
To cite: Tibana RA, Sousa NMF. Are extreme conditioning programmes effective and safe? A narrative review of high-intensity functional training methods research paradigms and findings. BMJ Open Sport \& Exercise Medicine 2018;4:e000435. doi:10.1136/ bmjsem-2018-000435
\end{abstract}

Accepted 3 October 2018
Check for updates

(c) Author(s) (or their employer(s)) 2018. Re-use permitted under CC BY-NC. No commercial re-use. See rights and permissions. Published by BMJ.

${ }^{1}$ Department of Physical Education, Federal University of Mato Grosso (UFMT), Cuiabá, MT, Brazil

${ }^{2}$ Laboratory of Exercise Physiology, Faculty Estacio of Vitoria, Vitoria, Brazil

Correspondence to Nuno Manuel Frade de Sousa; nunosfrade@gmail.com

\section{ABSTRACT}

Extreme conditioning programmes (ECPs, eg, CrossFit, Insanity and Gym Jones) are a growing fitness regimen characterised by functional movements performed at high-intensity and with constantly varying movements. While the popularity and number of practitioners of ECPs are growing, a debate has been established between what is observed in the scientific literature and anecdotal reports from athletes, coaches and physicians about safety (incidence and prevalence of injuries and rhabdomyolysis) and benefits (physical and mental health). In this article, we review the prevalence and incidence of injuries, rhabdomyolysis, physiological responses and chronic adaptations to ECPs. The majority of the available evidence confirm that the estimated injury rate among athletes participating in ECPs is similar to that in weightlifting and most other recreational activities. Additionally, ECP sessions resulted in increased acute oxidative, metabolic and cardiovascular stress, and depending on the stimulus (intensity, duration and non-usual exercise) and training status of the practitioner, an ECP session may precipitate rhabdomyolysis. In the scientific literature, the current chronic effects of ECPs showed little or no effects on body composition and improvements in physical fitness and psychological parameters; however, further studies are important.

\section{INTRODUCTION}

A relatively new form of exercise referred to as 'extreme conditioning programmes' (ECPs) is currently being marketed to a wide, active (athletes, military) and inactive population. ECPs (eg, CrossFit, Insanity, Gym Jones and others) often consist of a variety of training methods such as resistance training with kettlebells and barbells, repeated gym bodyweight exercises, explosive movements, sprints and flexibility. ${ }^{1-3}$ ECPs are characterised by a high training volume, including a variety of exercises performed at high-intensity and, often, at a fixed time to perform a number of repetitions or a specific task in

\section{Key messages}

- Extreme conditioning programmes (ECPs, eg, CrossFit, Insanity and Gym Jones) are a growing fitness regimen characterised by functional movements performed at high-intensity and with constantly varying movements.

- The majority of the available evidence confirms that the estimated injury rate among athletes participating in ECPs is similar to that in weightlifting and most other recreational activities.

- ECP sessions resulted in increased acute oxidative, metabolic and cardiovascular stress, and depending on the stimulus (intensity, duration and non-usual exercise) and training status of the practitioner, an ECP session may precipitate rhabdomyolysis.

the shortest possible time, with or without short rest periods between the series. ${ }^{1-3}$ These exercises are vigorous and physically demanding. According to Glassman ${ }^{4}$ —one of the founders of one type of world-renowned ECPs (CrossFit) - the goal with this type of training is to acquire a broad, comprehensive and inclusive fitness that will best prepare practitioners for any physical contingency.

Nowadays, these physical conditioning programmes are well-marketed and popularised, mainly due to their motivational and challenging character, which contributes to an exponential increase in the number of practitioners. ${ }^{56}$ There is a great number of individuals performing this type of physical exercises, from apparently healthy to even obese individuals ${ }^{7}$ or, as it is being popularised, by an adapted population. In addition, ECPs allow the participants to perform the exercises at locations other than gyms, also attracting individuals who are not adapted to traditional fitness centres.

However, the increased acceptance is reinforced through anecdotal reports of gains in 


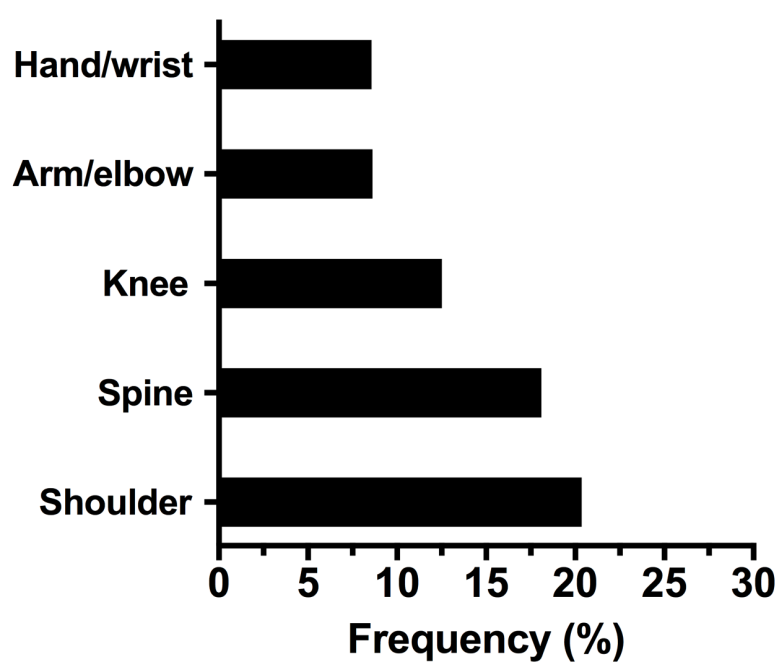

Figure 1 Summary of the most frequent injuries caused by extreme conditioning programmes reported by the different authors $^{10-15}$

physical fitness and performance. ${ }^{8}$ That is, there is still little scientific evidence to support the use of this type of programmes in the general population to improve physical fitness and health and, in addition, there are doubts about the safety of these exercises. Health benefits of ECPs are still underpinned by the integrated use of the most recent and major fitness trends, such as high-intensity interval training, group training, weight training, strength training and functional fitness, ${ }^{9}$ which have demonstrated strong evidence of improved cardiovascular health and improved insulin sensitivity and dyslipidaemias, in addition to functional fitness. On the other hand, these training programmes raise concerns in society and future athletes regarding safety and likelihood of causing injuries or illnesses. In this sense, three issues have gained attention with respect the safety of ECPs, namely: (1) use of fast movements with a high number of repetitions and insufficient rest intervals; (2) participants with a weak motor repertoire to perform complex movements and (3) a possible lack of educated, certified and experienced ECPs professionals, especially in the integration of all training methods. In this article, we review the prevalence and incidence of injuries, physiological responses and chronic adaptations to ECPs.

\section{Incidence and prevalence of injuries}

Little has been reported regarding the incidence and prevalence of injuries sustained secondarily to participation in an ECPs. Moreover, what constitutes an injury during ECPs has not been clearly defined and each article defines injury differently. A common concept of injury among authors that have assessed the incidence and prevalence of injuries caused by ECPs is any physical complaint that was sustained during ECPs training that results in a participant being unable to take part fully in ECPs training (eg, a time loss definition) or modification of normal training activities in duration, intensity or mode. ${ }^{10-14}$ In addition to the definition of injury, another difficulty found in the literature to establish a correct relationship between the practice of ECPs and injuries is the lack of information regarding the population studied, that is, the practice of ECPs by athletes/competitors or only by individuals whose goal is improving physical fitness and health. We emphasise the need of providing the correct description of samples in further studies, mainly because ECPs are increasingly being used by practitioners, whose goal is physical fitness and health, and athletes/competitors.

The first important conclusion about injuries in ECPs was described by Grier $e t a \hat{l}$ and was related to the types of injuries. Injuries in ECPs ranged from overuse injuries (stress fractures and reactions, tendonitis, shin splints and general musculoskeletal pain from repetitive microtraumas) and traumatic injuries (resulting from sudden force or forces applied to the body). ${ }^{3}$ The most frequent injuries caused by ECPs reported by the authors studied were those located in: shoulders; the spine, especially in the lumbar region; arms and elbows; hands and wrists; knees; hips and thighs; ankles; necks and chests and feet (figure 1). ${ }^{10-16}$ Hak et $a l^{13}$ affirm that the higher prevalence of shoulder injuries can be explained by their frequent submission to hyperflexion, internal rotation and abduction, placing the shoulders in a position of risk. Although the incidence of injuries is higher in the locomotor system, other injuries have been reported, such as retinal detachment and carotid dissection. ${ }^{17} 18$ Tibana $e t$ $a l^{19}$ have also pointed out the risk of exacerbated inflammatory response after ECPs.

There is a scarce number of studies in the literature addressing the incidence of injuries in practitioners of ECPs. Table 1 provides a summary of the injuries and descriptions provided in these studies. Klimek $e t a l^{20}$ state that the injury rate observed in ECPs is comparable or even lower than that caused by other common physical exercises or, even, strength training. However, Keogh and Winwood ${ }^{21}$ assessed competitors of different modalities and found that Strongman training (4.5-6.1 injuries per 1000 hours) and Highland Games (7.5 injuries per 1000 hours) were the modalities with the highest injury rates, which were substantially higher than that of bodybuilders, who exhibited the lowest injury rate (0.24-1 injuries per 1000 hours). When all strength modalities were compared, the injury rate was approximately 1-2 injuries per athlete/year and 2-4 injuries per 1000 hours of training/competitions. ${ }^{21}$ On the other hand, injury rates in sports such as football, rugby and cricket were 15-81 per 1000 hours of training/competitions. This way, when the incidence of injuries per 1000 hours of practice were assessed, the results observed in ECPs were smaller than those in sports such as rugby, football, volleyball, judo, tennis and cricket, which can exhibit rates of 15-81 injuries per 1000 hours of training/competitions. ${ }^{21}$

Some authors have attempted to establish relationships between injuries and characteristics of the trainings or the individuals. Grier $e t a \hat{l}$ assessed the prevalence 


\begin{tabular}{|c|c|c|c|c|c|c|c|}
\hline Study & Type of ECPs & Participants & Study design & $\begin{array}{l}\text { Study } \\
\text { duration }\end{array}$ & Injuries (n) & $\begin{array}{l}\text { Prevalence } \\
\text { of injuries } \\
(\%)\end{array}$ & $\begin{array}{l}\text { Incidence } \\
\text { of injuries } \\
\text { (injuries/1000 } \\
\text { hours) }\end{array}$ \\
\hline Aune and Powers ${ }^{15}$ & $\begin{array}{l}\text { Iron tribe } \\
\text { fitness }\end{array}$ & $\begin{array}{l}247 \text { iron tribe fitness athletes } \\
\text { (139 men) }\end{array}$ & $\begin{array}{l}\text { Prospective } \\
\text { Online questionnaire }\end{array}$ & 12 months & 132 & 34 & 2.71 \\
\hline Grier et al ${ }^{3}$ & $\begin{array}{l}\text { ATAC, RAW, } \\
\text { CrossFit }\end{array}$ & $\begin{array}{l}1393 \text { US soldiers ( } 1248 \text { men) } \\
26.8 \pm 5.9 \text { years }\end{array}$ & $\begin{array}{l}\text { Prospective } \\
\text { Face-to-face } \\
\text { questionnaire }\end{array}$ & 12 months & - & 41 & - \\
\hline Hak et $a l^{13}$ & CrossFit & $\begin{array}{l}132 \text { worldwide CrossFit } \\
\text { participants ( } 98 \text { men) } \\
32.3(19-57) \text { years }\end{array}$ & $\begin{array}{l}\text { Prospective } \\
\text { Online questionnaire }\end{array}$ & EC & 186 & 73.5 & 3.1 \\
\hline Mehrab et $a l^{14}$ & CrossFit & $\begin{array}{l}449 \text { Dutch CrossFit participants } \\
\text { ( } 266 \text { men) } \\
31.9 \pm 8.3 \text { years }\end{array}$ & $\begin{array}{l}\text { Prospective } \\
\text { Online }\end{array}$ & 12 months & 252 & 56.1 & - \\
\hline Montalvo et al $1^{10}$ & CrossFit & $\begin{array}{l}191 \text { South Florida CrossFit } \\
\text { participants ( } 94 \text { men) } \\
31.7 \pm 9.4 \text { years }\end{array}$ & $\begin{array}{l}\text { Prospective } \\
\text { Face-to-face } \\
\text { questionnaire }\end{array}$ & 6 months & 62 & 26.2 & 2.3 \\
\hline Moran et al ${ }^{11}$ & CrossFit & $\begin{array}{l}117 \text { UK CrossFit participants (66 } \\
\text { men) } \\
35 \pm 10 \text { years }\end{array}$ & $\begin{array}{l}\text { Prospective } \\
\text { Face-to-face } \\
\text { questionnaire }\end{array}$ & 12 weeks & 15 & - & 2.1 \\
\hline Summitt et al ${ }^{44}$ & CrossFit & 187 US CrossFit participants & $\begin{array}{l}\text { Prospective } \\
\text { Online } \\
\text { Shoulder injuries only }\end{array}$ & 6 months & 46 & 23.5 & 1,94 \\
\hline Weisenthal et $a l^{12}$ & CrossFit & $\begin{array}{l}386 \text { US CrossFit participants } \\
\text { (231 men) }\end{array}$ & $\begin{array}{l}\text { Prospective } \\
\text { Online }\end{array}$ & 6 months & 74 & 19.4 & 2.4 \\
\hline
\end{tabular}

ATAC, Advanced Tactical Athlete Conditioning; EC, entire career; ECPs, extreme conditioning programmes ; RAW, Ranger Athlete Warrior.

of injuries in American soldiers after the implementation of a ECPs in physical preparation routines before and after 6 months. The main reasons for the injuries (12\% of individuals injured) were low cardiorespiratory fitness, overweight/obesity and being smoker. In addition, it was observed that soldiers, both practitioners and non-practitioners of ECPs, who already had a habit of practising strength training, exhibited a lower incidence of injuries. Weisenthal $e t \mathrm{al}^{12}$ found a significantly higher incidence of ECPs-related injuries in men than in women. One explanation for such a difference was the greater demand of female athletes for CrossFit coaches. Factors such as proper use of load, correct execution of movement patterns and prioritisation of the technique rather than the performance to be achieved have been mentioned as important elements for the reduced rate of injuries in women. According to Montalvo et al, ${ }^{10}$ higher training volume and greater height and body mass were related to a higher incidence of injuries, which probably generated an increase in the load used during training routines. Among adults, different age groups did not exhibit a significant variation in the risk of injuries. This fact indicates that, in a safe and properly monitored environment, ECPs can function properly for adult and older athletes in all age groups. ${ }^{12}$ We cannot state the same conclusion for young practitioners because the lack of data; however, considering the correct monitored environment and the learning potential of new motor tasks, we can suppose the low risk of injuries among young practitioners. Finally, Mehrab et $a l^{14}$ observed that a short duration of participation ( $<6$ months) in ECPs was significantly associated with an increased risk for injury.

\section{Exertional rhabdomyolysis}

Rhabdomyolysis is a syndrome characterised by muscle necrosis followed by the release of intracellular muscle contents into the circulation. When rhabdomyolysis occurs due to exercise, it is termed 'exertional rhabdomyolysis'. Exertional rhabdomyolysis occurs in response to non-familiar and/or excessive, prolonged or repetitive exercises, with eccentric characteristics. ${ }^{22}$

Nowadays, with the rapid expansion of ECPs, reports of rhabdomyolysis have also increased (table 2). Pearcey et $a l^{23}$ reported the occurrence of rhabdomyolysis in an athlete who, after 3 months without training, initiated the practice of high-intensity sports in a sudden and intense manner. According to the authors, the athlete's subjective notion of myalgia was impaired due to intense motivation and the use of pre-workout supplement. Meyer et $a l^{24}$ emphasised the seriousness of rhabdomyolysis and reported its occurrence in a previously healthy 31-year-old woman. Despite being a regular practitioner who performed exercises four times a week, she exhibited the syndrome after the first CrossFit training. The authors also argued that myoglobinuria and myalgia were not mandatory findings, given that only $50 \%$ of the cases exhibited the characteristic exacerbated muscular pain. This is why the main diagnostic criterion is based on laboratory quantification of creatine kinase (CK). Additionally, 
Table 2 Summary of the ECPs induced rhabdomyolysis

\begin{tabular}{|c|c|c|c|c|c|}
\hline Study & Type of ECPs & Subject & Study design & Physical status & Protocol of ECPs \\
\hline Hadeed et $a l^{45}$ & CrossFit & Man & Case report & $\begin{array}{l}\text { He reports having had five previous days } \\
\text { of exercise but did not involve CrossFit } \\
\text { type training. }\end{array}$ & Non-informed. \\
\hline Pearcey et $a l^{23}$ & Non-informed & Man & Case report & $\begin{array}{l}\text { Athlete who was acutely detrained } \\
\text { (approximately } 3 \text { months). }\end{array}$ & $\begin{array}{l}48 \text { alternating sets ( } 60 \text { s duration) of } \\
\text { push-up and pull-up variations. The } \\
\text { subject performed the maximum number } \\
\text { of repetitions possible of push-ups or } \\
\text { pull-ups in each set. The total exercise } \\
\text { duration was } 48 \text { min. The subject } \\
\text { performed approximately } 400 \text { push-ups } \\
\text { and approximately } 200 \text { pull-ups in } 48 \text { min. }\end{array}$ \\
\hline
\end{tabular}

\begin{tabular}{|c|c|c|c|c|}
\hline Wagner et $a l^{46}$ & Non-informed & Woman & Case report & $\begin{array}{l}\text { A healthy } 21 \text {-year-old Caucasian woman } \\
\text { was participating in an organised, } \\
\text { extreme exercise workout session } \\
\text { conducted at a fitness centre. }\end{array}$ \\
\hline $\begin{array}{l}\text { Lozowska et } \\
a^{25}\end{array}$ & CrossFit & $\begin{array}{l}\text { Five of six } \\
\text { patients were } \\
\text { women }\end{array}$ & Case series & $\begin{array}{l}\text { Three of the six patients were very } \\
\text { physically fit before experiencing } \\
\text { rhabdomyolysis, having participated } \\
\text { in CrossFit for months to years. The } \\
\text { remaining three patients were less fit and } \\
\text { sustained rhabdomyolysis after their first } \\
\text { encounter with CrossFit. }\end{array}$ \\
\hline
\end{tabular}

\begin{tabular}{|c|c|c|c|c|}
\hline $\begin{array}{l}\text { Aynardi and } \\
\text { Jones }^{47}\end{array}$ & Non-informed & $\begin{array}{l}\text { A 43-year- } \\
\text { old African } \\
\text { American } \\
\text { woman }\end{array}$ & Case report & $\begin{array}{l}\text { She was healthy overall and had been } \\
\text { active in multiple gym-related exercise } \\
\text { programme over the past } 10 \text { years. }\end{array}$ \\
\hline Meyer et $a l^{24}$ & CrossFit & $\begin{array}{l}\text { A previously } \\
\text { healthy } \\
31 \text {-year-old } \\
\text { woman }\end{array}$ & Case report & $\begin{array}{l}\text { She was exercising regularly four times } \\
\text { per week, performing push-ups, running } \\
\text { and other physical workouts. }\end{array}$ \\
\hline
\end{tabular}

\begin{tabular}{|c|c|c|c|c|}
\hline Honda et $a l^{48}$ & Non-informed & $\begin{array}{l}\text { A previously } \\
\text { healthy } \\
37 \text {-year-old } \\
\text { man }\end{array}$ & Case report & $\begin{array}{l}\text { He had exercised regularly but had never } \\
\text { performed such intense training before. }\end{array}$ \\
\hline Routman et al ${ }^{49}$ & CrossFit & $\begin{array}{l}\text { Two previously } \\
\text { healthy } \\
\text { women; } 36 \\
\text { years (case 1) } \\
\text { and } 37 \text { years } \\
\text { (case 2) }\end{array}$ & Case report & $\begin{array}{l}\text { Case 1. A } 27 \text {-year-old healthy woman } \\
\text { with a BMI of } 22 \mathrm{~kg} / \mathrm{m}^{2} \text {. She was a long- } \\
\text { distance runner with no noteworthy } \\
\text { medical or surgical history and was not } \\
\text { taking any medications; Case } 2 \text {. A healthy } \\
26 \text {-year-old woman with a BMl of } 34 \mathrm{~kg} / \\
\mathrm{m}^{2}\end{array}$ \\
\hline
\end{tabular}

The exercise session consisting of performing a designated number of push-ups in $1 \mathrm{~min}$. The protocol dictated 5 push-ups in the first minute, 10 in the second and adding 5 push-ups each minute until participants can no longer continue. She recalls completing 6 rounds of increasing repetitions in each minute, thereby performing 105 push-ups in 6 $\min$.

Non-informed. ups,

The ECPs consisted of a standard warmup followed by 3 sets of chin-ups that were performed until 'failure' lasting approximately $20 \mathrm{~min}$.

The subject denied recent trauma or illness but reported performing a variety of high-intensity exercises such as push-

Intense exercise training that included 100 push-ups, 100 exercises using a 20 kg dumbbell, 50 lifts using a 10 kg weight

The two cases of isolated infraspinatus rhabdomyolysis following exertional overuse after a challenge known as the 'Sissy Test'. This challenge involves up to 336 kettlebell swings and 336 squat-thrust push-ups (also known as 'burpees') in an allotted time frame of 30 min. Beginning with 15 kettlebell swings and 1 burpee, the workout challenge is repeated with a descending number of kettlebell swings and a corresponding ascending number of burpees. This is continuously repeated until the final set of 1 kettlebell swing and 15 burpees has been performed.

\begin{tabular}{|c|c|c|c|c|c|}
\hline Tibana et $a l^{27}$ & $\begin{array}{l}\text { Extreme } \\
\text { conditioning } \\
\text { competition }\end{array}$ & $\begin{array}{l}\text { A 35-year- } \\
\text { old woman } \\
\text { without } \\
\text { medical history } \\
\text { of disease }\end{array}$ & Case report & $\begin{array}{l}\text { She was healthy overall and had been } \\
\text { active in ECPs over the previous } 5 \text { years } \\
\text { and trained } 4-5 \text { times per week. }\end{array}$ & $\begin{array}{l}\text { ECPs competition lasting } 2 \text { days and } \\
\text { composed of five workouts. One workout } \\
\text { consisted of } 60 \text { repetitions for an } \\
\text { unaccustomed exercise (GHD). }\end{array}$ \\
\hline
\end{tabular}

BMI, body mass index; ECPs, extreme conditioning programmes; GHD, glutes-hamstring developer.

in a study conducted with a greater number of cases, Lozowska et $a l^{25}$ reported six events of rhabdomyolysis associated with CrossFit practice. Previously healthy patients-some of them with considerable experience with the modality and no family history-had exhibited manifestations such as exacerbated myalgia after the first 24 hours of training, especially in the muscular regions which were more vigorously demanded during 
the exercise. Half of them had good physical fitness before the event, having practised the modality from months to years. It should be noted that the onset of clinical manifestations does not occur immediately after physical exertion, as reported by Larsen et al, ${ }^{26}$ who found that signs and symptoms had only appeared 3 days after the training that had given rise to the condition. Recently, Tibana $e t a l^{27}$ described an instance of exercise-induced rhabdomyolysis, caused by an ECPs competition, in a 35-year-old woman who presented with abdominal pain and soreness, which began 1 day after she had completed 2 days of an ECPs competition composed of five workouts. Interestingly, although she had more than 5 years of experience in ECPs, during the competition, one workout consisted of 60 repetitions of glutes-hamstring developer (unaccustomed exercise) that precipitated the rhabdomyolysis.

These results indicate that coaches and trainers of ECPs should be aware of the risk and should maybe consider prescribing lower volume and intensity sessions in non-usual exercises to minimise the risk of rhabdomyolysis (including in the weeks before a competition). The inclusion of unaccustomed exercise with volume and intensity similar to a competition will induce cellular protection; this phenomenon is known as the 'repeated bout effect'. Finally, we must rethink current ECPs strategies to improve athletic performance, because unfortunately exertional rhabdomyolysis is becoming increasingly more prevalent in ECP practitioners. We believe that the periodisation of the programme, taking into account the progressive increase in volume and intensity in non-usual exercises, could be the best way to prevent certain undesired events, such as rhabdomyolysis.

\section{Physiological responses to an extreme conditioning programmes session}

The physiological demands during ECPs have been quantified via the measurement of heart rate (HR) ${ }^{19}$ blood lactate concentration, ${ }^{28}$ catecholamines and cytokines. ${ }^{28}$ The results are described in table 3. During ECPs, the $\mathrm{HR}_{\max }$ percentage measured during the short session $(<5 \mathrm{~min})$ was $92.7 \% \pm 4 \%$, while the long session (15 min) elicited a $91.3 \% \pm 3 \%$ HRmax. ${ }^{29}$ Tibana et $a l^{19}$ and Kliszczewicz et $a l^{30}$ reported in trained men that immediately postexercise HRs were almost always above $80 \%$ HRmax. Interestingly, Tibana et $a l^{19}$ showed that the ECPs employing Olympic weightlifting exercises during the metabolic condition induced a higher increase in HR $(86 \% \pm 11 \%$ of HRmax) compared with an ECPs session without Olympic weightlifting exercise $(82 \% \pm 12 \%$ of HRmax $)$.

Blood lactate concentration values measured after ECPs have provided evidence of high metabolic involvement in this programme. Immediate postexercise sampling revealed very high values in both trained and untrained practitioners, ranging from 9.0 2.5 $\mathrm{mmol} / \mathrm{L}$ to $17.8 \pm 4.9$ for trained to $14.2 \pm 2.3 \mathrm{mmol} / \mathrm{L}$ for untrained (table 3). Nonetheless, the session duration does not implicate in different metabolic response, as reported by Kliszczewicz et $a l^{29}$ and Maté-Muñoz et $a l .{ }^{31}$ Figure 2 shows a summary of blood lactate concentration, rating of perceived exertion (RPE) and HR responses presented in the available papers related to ECPs.

In terms of the hormonal and cytokine responses after ECPs, Kliszczewicz et $a l^{29}$ demonstrated significant elevations of plasma epinephrine $(685 \% \pm 601 \%$, $620 \% \pm 358 \%)$ and norepinephrine $(779 \% \pm 313 \%$, $736 \% \pm 271 \%$ ) immediately postexercise following short and long sessions of ECPs; however, the authors found no difference between the short and long ECP sessions in terms of catecholamine concentrations. Heavens $e t$ $a l^{32}$ noted a transient change of testosterone $(\sim 25 \mathrm{nmol}$ $\mathrm{L}^{-1}$ in men) and cortisol (mean \pm SD men: $1,247.4 \pm 364.0$ nmol L $\mathrm{L}^{-1}$; mean $\pm \mathrm{SD}$ women: 985.2 $\pm 438.1 \mathrm{nmol} \mathrm{L}^{-1}$ ), with the highest mean values observed at $15 \mathrm{~min}$ postexercise. However, 24 hours postexercise, these values were normalised. With regard to the cytokine response, Tibana $e t a l^{28}$ found that training sessions of ECPs elicited significant increases in interleukin (IL)-6 (session 1: $197 \% \pm 109 \%$ and session 2: $99 \% \pm 58 \%$ ), IL-10 displayed an increase immediately after session $1(44 \pm 52 \%)$ and decreased 24 and 48 hours following session 2, and although not statistically significant, IL-10/IL-6 decreased 24 hours $(\sim 50 \%)$ and 48 hours $(\sim 50 \%)$ after session 2 when compared with baseline. Similarly, Heavens et $a l^{32}$ showed that a high-intensity with a short-rest protocol (which consisted of a descending pyramid scheme of back squat, bench press and deadlift, beginning with 10 repetitions of each, then 9 , then 8 and so on until 1 repetition on the final set) elicits a significant increase in inflammation (IL-6 immediately postexercise for men: $\sim 3 \mathrm{pg} / \mathrm{mL}$; women: 3.5 pg/mL).

These results indicate that ECPs elicited a higher metabolic, cardiovascular, hormonal and inflammation response. Therefore, strength and conditioning professionals need to be aware of the level of stress imposed on individuals when performing metabolic workouts of ECPs. While future research is needed to determine the significance of this result, it is recommended that the incorporation of lower intensity sessions (eg, through the rating of perceived exertion or HR) and/or resting days would help to minimise this exacerbated physiological response.

\section{Chronic adaptations to extreme conditioning programmes}

Current ECP studies that investigated the chronic effects are based on changes in body composition, fitness and psychophysiological parameters in both sedentary and physically active participants. Heinrich $e t a l^{7}$ evaluated the body composition of eight sedentary men and eight sedentary women after 8 weeks of ECPs training and no significant changes were observed in body mass index, fat mass or lean body mass. Despite the unchanged 


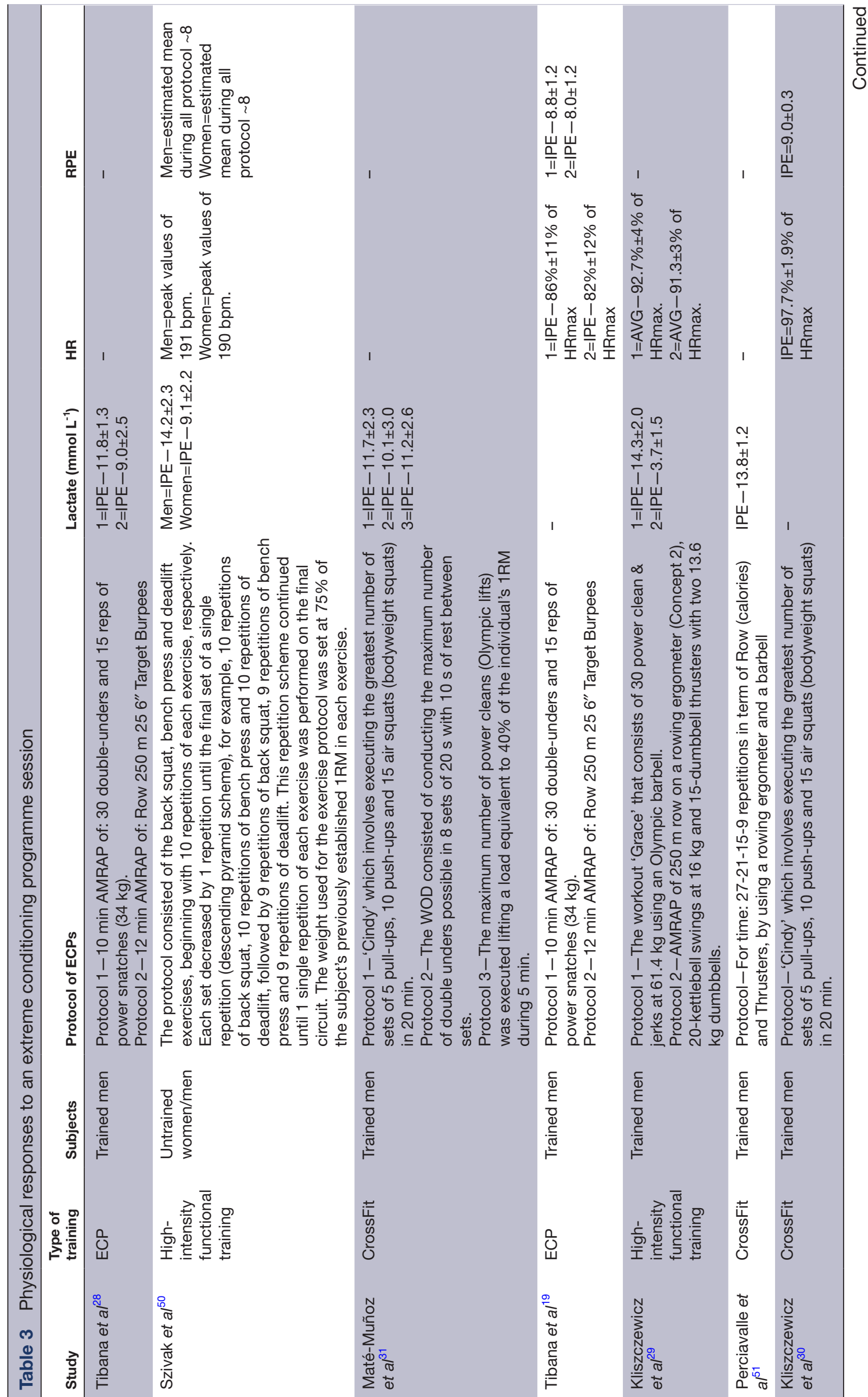



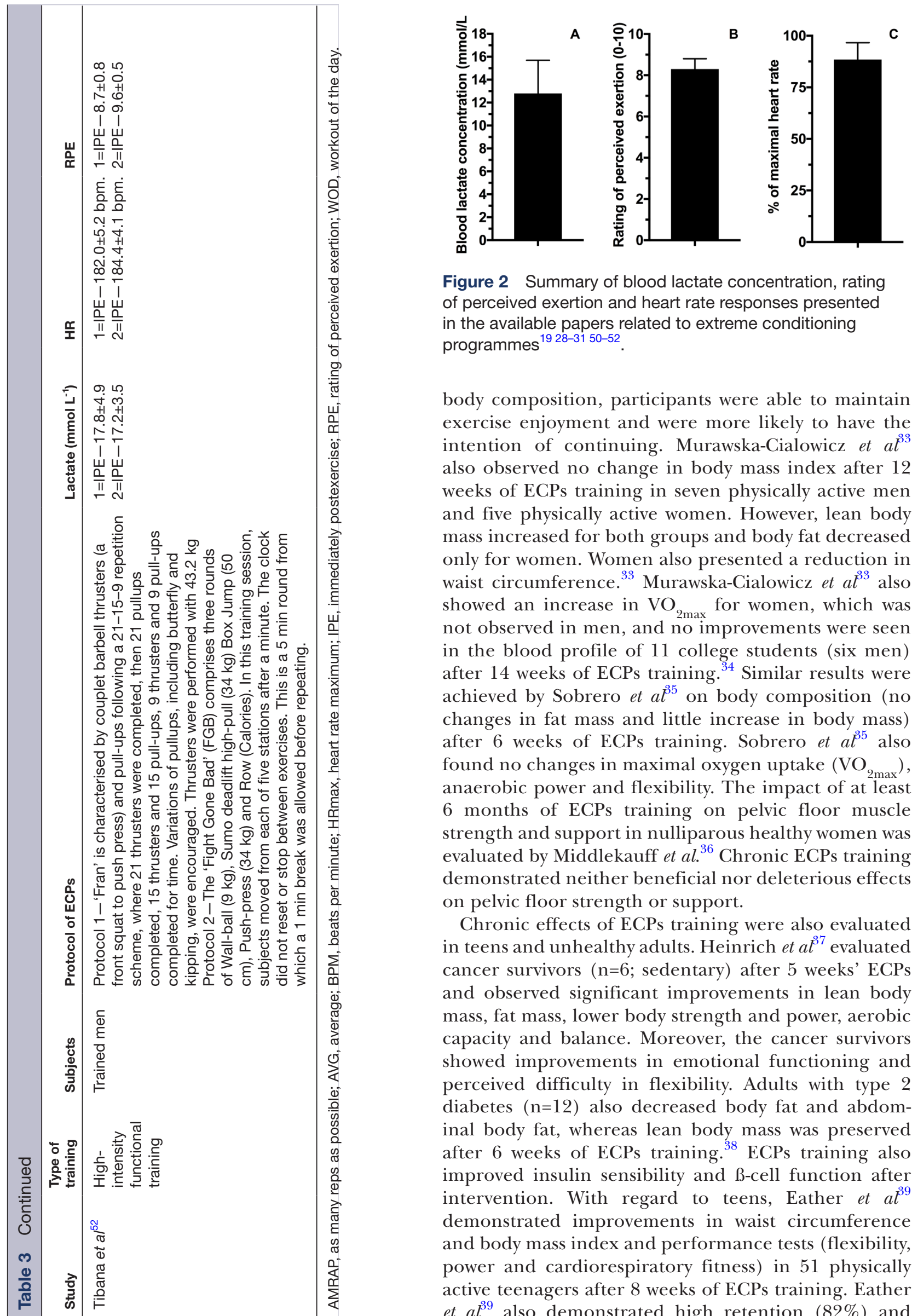

Figure 2 Summary of blood lactate concentration, rating of perceived exertion and heart rate responses presented in the available papers related to extreme conditioning programmes $^{1928-3150-52}$.

body composition, participants were able to maintain exercise enjoyment and were more likely to have the intention of continuing. Murawska-Cialowicz et $a l^{33}$ also observed no change in body mass index after 12 weeks of ECPs training in seven physically active men and five physically active women. However, lean body mass increased for both groups and body fat decreased only for women. Women also presented a reduction in waist circumference. ${ }^{33}$ Murawska-Cialowicz $e t a l^{33}$ also showed an increase in $\mathrm{VO}_{2 \max }$ for women, which was not observed in men, and no improvements were seen in the blood profile of 11 college students (six men) after 14 weeks of ECPs training. ${ }^{34}$ Similar results were achieved by Sobrero et $a l^{35}$ on body composition (no changes in fat mass and little increase in body mass) after 6 weeks of ECPs training. Sobrero et $a l^{35}$ also found no changes in maximal oxygen uptake $\left(\mathrm{VO}_{2 \max }\right)$, anaerobic power and flexibility. The impact of at least 6 months of ECPs training on pelvic floor muscle strength and support in nulliparous healthy women was evaluated by Middlekauff et al. ${ }^{36}$ Chronic ECPs training demonstrated neither beneficial nor deleterious effects on pelvic floor strength or support.

Chronic effects of ECPs training were also evaluated in teens and unhealthy adults. Heinrich $e t a l^{37}$ evaluated cancer survivors $(\mathrm{n}=6$; sedentary) after 5 weeks' ECPs and observed significant improvements in lean body mass, fat mass, lower body strength and power, aerobic capacity and balance. Moreover, the cancer survivors showed improvements in emotional functioning and perceived difficulty in flexibility. Adults with type 2 diabetes $(n=12)$ also decreased body fat and abdominal body fat, whereas lean body mass was preserved after 6 weeks of ECPs training. ${ }^{38}$ ECPs training also improved insulin sensibility and B-cell function after intervention. With regard to teens, Eather et $a l^{39}$ demonstrated improvements in waist circumference and body mass index and performance tests (flexibility, power and cardiorespiratory fitness) in 51 physically active teenagers after 8 weeks of ECPs training. Eather et $a l^{39}$ also demonstrated high retention $(82 \%)$ and 
adherence $(94 \%)$ rates to ECPs training. ECPs practice during physical education lessons has shown high levels of enjoyment, effort and learning perception in the students $(n=104)$ after 8 weeks of training. ${ }^{40}$ On the other hand, Eather et $a l^{41}$ showed that 8 weeks of ECPs training by teens did not improve mental health outcomes in all the students $(n=51)$. However, in adolescents 'at risk' of developing psychological disorders, ECPs training improved mental health. Last, Ward et $a t^{42}$ showed significant improvements in the progressive aerobic cardiovascular endurance run, push-ups and curl-ups tests of the FITNESSGRAM and health-related fitness knowledge after 20 lessons of ECPs in 166 fifth-grade students ( 76 boys, 90 girls). To date, current chronic effects of ECPs scientific literature showed little or no effects on body composition and improvements in physical fitness and psychological parameters; however, further studies are important. Figure 3 shows



\section{Physiological responses

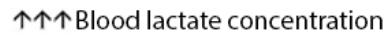

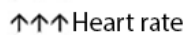

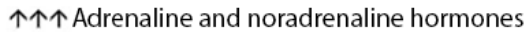

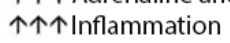

\section{Risks}

- Exertional rhabdomyolysis

- Overuse and traumatic injuries

- Non-functional overreaching / overtraining syndrome

Figure 3 Extreme conditioning programme characteristics, possible chronic adaptions of each foundational modalities, physiological responses and potential risks. 
a summary of the ECP characteristics, possible chronic adaptions of each foundational modalities, physiological responses and potential risks.

Psychological effects of ECPs are yet less studied. However, based on the rapid growth and popularity of the programme, it is apparent that ECPs provide an appealing fitness option for many individuals. Sibley and Bergman ${ }^{43}$ state that several specific aspects of the ECPs are noteworthy in their potential impact on goal contents and basic psychological need satisfaction. Applying these aspects in exercise contexts, in general, may facilitate participants' autonomous motivation and increase participation levels. Sibley and Bergman ${ }^{43}$ also showed that ECP participants primarily strive for goals related to health management and skill development, with physique enhancement and social affiliation being of secondary importance. Social recognition was the lowest rated goal. On the other hand, Lichtenstein et $a \tilde{e}$ showed that the prevalence of exercise addiction in CrossFit was $5 \%$ and was similar to the prevalence rates in other sport populations.

\section{CONCLUSION}

The majority of the available evidence presented in this paper confirms that the estimated injury rate among athletes participating in ECPs is similar to the rate of injury in weightlifting and most other recreational activities. Additionally, ECP sessions resulted in increased acute oxidative, metabolic and cardiovascular stress, and depending on the stimulus (intensity, duration or non-usual exercise) and training status of the practitioner, an ECPs session may precipitate rhabdomyolysis. There is an alarming increase in case reports of rhabdomyolysis after ECPs. Current ECP studies that have investigated the chronic effects are based on changes in body composition, fitness and psychophysiological parameters in sedentary and physically active participants. The ECPs scientific literature showed few or no chronic effects on body composition and improvements in physical fitness and psychological parameters; however, further studies are important.

Contributors RAT and NMFdS contributed to the conception, design, research and writing on this manuscript. All authors have read and approved the final manuscript.

Funding NMFdS declared a grant by the Research and Productivity Program of the Faculty Estacio of Vitoria (2018)

Competing interests None declared.

Patient consent Not required.

Provenance and peer review Not commissioned; internally peer reviewed.

Open access This is an open access article distributed in accordance with the Creative Commons Attribution Non Commercial (CC BY-NC 4.0) license, which permits others to distribute, remix, adapt, build upon this work non-commercially, and license their derivative works on different terms, provided the original work is properly cited, appropriate credit is given, any changes made indicated, and the use is non-commercial. See: http:// creativecommons.org/licenses/by-nc/4.0/

\section{REFERENCES}

1. Sprey JW, Ferreira T, de Lima MV, et al. An epidemiological profile of crossfit athletes in Brazil. Orthop J Sports Med 2016;4:2325967116663706

2. Fisker FY, Kildegaard S, Thygesen M, et al. Acute tendon changes in intense crossfit workout: an observational cohort study. Scand J Med Sci Sports 2017;27:1258-62.

3. Grier T, Canham-Chervak M, McNulty V, et al. Extreme conditioning programs and injury risk in a US army brigade combat team. US Army Med Dep J 2013:36-47.

4. Glassman G. Understanding crossfit. CrossFit Journal 2007;56.

5. Lichtenstein MB, Jensen TT. Exercise addiction in crossfit: prevalence and psychometric properties of the exercise addiction inventory. Addict Behav Rep 2016;3:33-7.

6. Belger AW. The power of community: crossfit and the force of human connection. Victory Belt Publishing, 2012.

7. Heinrich KM, Patel PM, O'Neal JL, et al. High-intensity compared to moderate-intensity training for exercise initiation, enjoyment, adherence, and intentions: an intervention study. BMC Public Health 2014; 14:789.

8. Bergeron MF, Nindl BC, Deuster PA, et al. Consortium for health and military performance and american college of sports medicine consensus paper on extreme conditioning programs in military personnel. Curr Sports Med Rep 2011;10:383-9.

9. Thompson WR. Worldwide survey of fitness trends for 2018: the CREP Edition. ACSM's Health \& Fitness Journal 2017;21:10-19.

10. Montalvo AM, Shaefer H, Rodriguez B, et al. Retrospective injury epidemiology and risk factors for injury in crossfit. J Sports Sci Med 2017;16:53-9.

11. Moran S, Booker H, Staines J, et al. Rates and risk factors of injury in crossfitTM: a prospective cohort study. J Sports Med Phys Fitness 2017;57:1147-53.

12. Weisenthal BM, Beck CA, Maloney MD, et al. Injury rate and patterns among crossfit athletes. Orthop J Sports Med 2014;2:2325967114531177.

13. Hak PT, Hodzovic E, Hickey B. The nature and prevalence of injury during crossfit training. J Strength Cond Res 2013:1.

14. Mehrab M, de Vos RJ, Kraan GA, et al. Injury incidence and patterns among Dutch crossfit athletes. Orthop J Sports Med 2017;5:2325967117745263.

15. Aune KT, Powers JM. Injuries in an extreme conditioning program. Sports Health 2016.

16. Winwood PW, Hume PA, Cronin JB, et al. Retrospective injury epidemiology of strongman athletes. J Strength Cond Res 2014;28:28-42

17. Lu A, Shen P, Lee P, et al. CrossFit-related cervical internal carotid artery dissection. Emerg Radiol 2015;22:449-52.

18. Joondeph SA, Joondeph BC. Retinal detachment due to crossfit training injury. Case Rep Ophthalmol Med 2013;2013:189837-2.

19. Tibana RA, Almeida LM, DE Sousa Neto IV, et al. Extreme conditioning program induced acute hypotensive effects are independent of the exercise session intensity. Int J Exerc Sci 2017;10:1165-73.

20. Klimek C, Ashbeck C, Brook AJ, et al. Are injuries more common with CrossFit training than other forms of exercise? J Sport Rehabil 2018;27:295-9.

21. Keogh JW, Winwood PW. The epidemiology of injuries across the weight-training sports. Sports Med 2017;47:479-501.

22. Alpers JP, Jones LK. Natural history of exertional rhabdomyolysis: a population-based analysis. Muscle Nerve 2010;42:487-91.

23. Pearcey GE, Bradbury-Squires DJ, Power KE, et al. Exertional rhabdomyolysis in an acutely detrained athlete/exercise physiology professor. Clin J Sport Med 2013;23:496-8.

24. Meyer M, Sundaram S. Schafhalter-Zoppoth i. exertional and crossfit-induced rhabdomyolysis. Clin J Sport Med 2017.

25. Lozowska D, Liewluck T, Quan D, et al. Exertional rhabdomyolysis associated with high intensity exercise. Muscle Nerve 2015;52:1134-5.

26. Larsen C, Jensen MP. Rhabdomyolysis in a well-trained woman after unusually intense exercise. Ugeskr Laeger 2014;176.

27. Tibana RA, Sousa NMF, Cunha GV, et al. Exertional Rhabdomyolysis after an extreme conditioning competition: a case report. Sports 2018;6:40.

28. Tibana RA, de Almeida LM, Frade de Sousa NM, et al. Two consecutive days of crossfit training affects pro and antiinflammatory cytokines and osteoprotegerin without impairments in muscle power. Front Physiol 2016;7:260.

29. Kliszczewicz B, Williamson C, Bechke E, et al. Autonomic response to a short and long bout of high-intensity functional training. J Sports Sci 2018:1-8. 
30. Kliszczewicz B, Quindry CJ, Blessing LD, et al. Acute exercise and oxidative stress: crossfit vs. treadmill bout. J Hum Kinet 2015;47:81-90.

31. Maté-Muñoz JL, Lougedo JH, Barba M, et al. Muscular fatigue in response to different modalities of crossfit sessions. PLoS One 2017;12:e0181855.

32. Heavens KR, Szivak TK, Hooper DR, et al. The effects of high intensity short rest resistance exercise on muscle damage markers in men and women. J Strength Cond Res 2014;28:1041-9.

33. Murawska-Cialowicz E, Wojna J, Zuwala-Jagiello J. Crossfit training changes brain-derived neurotrophic factor and irisin levels at rest, after wingate and progressive tests, and improves aerobic capacity and body composition of young physically active men and women. $J$ Physiol Pharmacol 2015;66:811-21.

34. Choi EJ, So WY, Jeong TT. Effects of the crossfit exercise data analysis on body composition and blood profiles. Iran J Public Health 2017;46:1292-4.

35. Sobrero G, Arnett S, Schafer M, et al. A comparison of high intensity functional training and circuit training on health and performance variables in women: a pilot study. Women in Sport and Physical Activity Journal 2017;25:1-10.

36. Middlekauff ML, Egger MJ, Nygaard IE, et al. The impact of acute and chronic strenuous exercise on pelvic floor muscle strength and support in nulliparous healthy women. Am J Obstet Gynecol 2016;215:316.e1-316.e7

37. Heinrich KM, Becker C, Carlisle T, et al. High-intensity functional training improves functional movement and body composition among cancer survivors: a pilot study. Eur J Cancer Care 2015;24:812-7.

38. Nieuwoudt S, Fealy CE, Foucher JA, et al. Functional high-intensity training improves pancreatic $\beta$-cell function in adults with type 2 diabetes. Am J Physiol Endocrinol Metab 2017;313:E314-20.

39. Eather N, Morgan PJ, Lubans DR. Improving health-related fitness in adolescents: the crossfit teen ${ }^{\mathrm{TM}}{ }^{\mathrm{M}}$ randomised controlled trial. $J$ Sports Sci 2016;34:209-23.

40. Sánchez-Alcaraz Martínez BJ, Gómez-Mármol A, esfuerzo Percepción de. Percepción de esfuerzo, diversión y aprendizaje en alumnos de educación secundaria en las clases de Educación
Física durante una Unidad Didáctica de CrossFit. SPORT TK-Revista EuroAmericana de Ciencias del Deporte 2015;4:63-8.

41. Eather N, Morgan PJ, Lubans DR. Effects of exercise on mental health outcomes in adolescents: findings from the crossfit TM teens randomized controlled trial. Psychol Sport Exerc 2016;26:14-23.

42. Ward JK, Hastie PA, Wadsworth DD, et al. A sport education fitness season's impact on students' fitness levels, knowledge, and in-class physical activity. Res Q Exerc Sport 2017;88:346-51.

43. Sibley BA, Bergman SM. What keeps athletes in the gym? Goals, psychological needs, and motivation of crossfit ${ }^{\mathrm{TM}}$ participants. International Journal of Sport and Exercise Psychology 2017:1-20.

44. Summitt RJ, Cotton RA, Kays AC, et al. Shoulder injuries in individuals who participate in crossfit training. Sports Health 2016;8:541-6.

45. Hadeed MJ, Kuehl KS, Elliot DL, et al. Exertional rhabdomyolysis after crossfit exercise program. Medicine \& Science in Sports \& Exercise 2011;43:224-5.

46. Wagner M, LeNorman D, Dooley A, et al. Recurrent Rhabdomyolysis and extreme exercise-a case study. Journal of Sports Medicine and Allied Health Sciences: Official Journal of the Ohio Athletic Trainers Association 2015;1.

47. Aynardi MC, Jones CM. Bilateral upper arm compartment syndrome after a vigorous cross-training workout. J Shoulder Elbow Surg 2016;25:e65-e67.

48. Honda S, Kawasaki T, Kamitani T, et al. Rhabdomyolysis after high intensity resistance training. Intern Med 2017:56:1175-8.

49. Routman HD, Triplet JJ, Kurowicki J, et al. Isolated rhabdomyolysis of the infraspinatus muscle following the crossfit "sissy test": a report of two cases. JBJS Case Connect 2018;8:e2.

50. Szivak TK, Hooper DR, Dunn-Lewis C, et al. Adrenal cortical responses to high-intensity, short rest, resistance exercise in men and women. J Strength Cond Res 2013;27:748-60.

51. Perciavalle V, Marchetta NS, Giustiniani S. Attentive processes, blood lactate and crossfit((R)). Phys Sportsmed 2016;44:403-6.

52. Tibana RA, de Sousa NMF, Cunha GV, et al. Validity of session rating perceived exertion method for quantifying internal training load during high-intensity functional training. Sports 2018;6:E68:68 